\title{
Search for Identity: A Study of Manju Kapur's Difficult Daughters
}

\author{
Dr Neelam Hooda \\ Assistant Professor \\ Department of English and Foreign Languages \\ Maharshi Dayanand University \\ Rohtak, India \\ neelammor@gmail.com
}

\begin{abstract}
This paper presents the woman as a person who fights against concealment and mistreatment of the male-controlled society. The novel Difficult Daughters reasonably shows the situation of ladies and her aching battle to build up an identity. Manju Kapur has come out as a genuine social scholar in her novels in light of the fact that there is a reason behind her composition. Her novels has been composed with a distinct reason in the light of the fact that the author attempts to dissect issues identified with the working class or upper white-collar class women. Manju Kapur is greatly intrigued to present the inquiries and issues identified with women's from larger point of view. In her novels, the questions have developed basically with regards to the identity of the educated working-class women. Manju Kapur's female protagonists are generally well-read. They are resilient people yet detained inside the limit of moderate society. Their instruction drives them to free speculation for which their family and society become unbearable to them, in their individual fight with family and society through which they dove into a committed exertion to look a personality for them as the qualified woman with flawless foundation. The author has depicted her protagonist as
\end{abstract}


woman trapped in the contention between the interests of the fragile living creature and longing to be a piece of the political and scholarly society of today.

Keywords: Concealment, White-Collar, Speculation, Exertion, Contention, Fragile

The greater part of the number of inhabitants on the planet is made of woman however she isn't treated comparably to man regardless of multitudinous developments and unrests. She has the equivalent mental and good force, yet she isn't perceived as his equivalent. In such conditions, the subject of looking through her identity is advocated. As a matter of fact, in his male overwhelmed society, she is a spouse, mother, sister and home creator. She is relied upon to serve, penance, submit and endure each sick against her calmly. Her individual self has almost no acknowledgement in the male-centric culture thus selfeffacement is her ordinary lifestyle. The representation of Sita, Savitri and Gandhari are constantly expected to be followed by her. In any case, the observable point is that these perfect women's existed uniquely in legends, they were princesses what's more, sovereigns and such a long way from the agonies and sufferings in the current world in which presentday woman has no identity of her own. She lives for other people and relaxes for other people. What's more, the circumstance turns out to be all the more destructive when we take it in an Indian setting where a woman must concede to her significant other and make the conjugal home wonderful for him. Manju Kapur, a world-acclaimed novelist is known for her feministic vision. The female protagonists in her novels appear to be the representation of a new woman who has been worrying about the concern of restraint since ages and needs to break that convention of quietness now. In the conventional social milieu of her novels, she shows the presence of mothers also, little girls, it is a similar society where marriage is viewed as a definitive objective and fate from which these women can't escape. Manju Kapur's female protagonists are the agents of that female society who long to be liberated 
from the stale social traditions and customs however are never permitted. Her female protagonists are, for the most part, instructed. Their training drives them to free intuition, for which their family and society get narrow-minded towards them. They battle among convention and innovation. It is their individual battle with family and society through which they dive into a devoted exertion to cut a personality for themselves as qualified women with perfect foundations. Her novels tackle the identity issues looked by the educated Indian woman with authenticity and knowledge. These novels represent a battle against restrictions, social limitations and set of principles in a customary society. Her heroines are the images of female imaginations reacting to pressures and mistreatments of a male-centric culture where marriage is considered distinctly to be a compromise. Her novels are an account of the battle for an opportunity also, look for an identity at different levels. She tries to bring out critical new implications in the changed model of cultural experiences in which marital jobs, dual burden, equivalent chances and social requirements are seen from the existential perspective. The protagonists of her novels are attempting to keep up a balance constantly. Their sufferings in the midst of the double norms have made them solid and they continually fight to exist, to liberate themselves from the shackles of convention and different biases.

In the novel Difficult Daughters, the author has depicted her protagonists as a woman trapped in the contention between the enthusiasm of the fragile living creature and a longing to be a piece of the political and scholarly developments of the day. The central character of the novel opposes custom. The title of the novel Difficult Daughters is a sign to the message that a woman, who endeavors to look for an identity, is marked as the difficult daughter by the family as well as society. Difficult Daughters presents a woman who attempts to build up their own identity. Sunita Sinha asserts, "Kapur speaks of the idea of independence- independence 
aspired to and obtained by a nation and also independence yearned after by a woman.” (Sinha, 2)

The tale of Virmati is described by her own little girl, Ida. The novel starts with the passing of the protagonist, Virmati. Ida clarifies the account of her dead mother. Manju Kapur, so as to think about the story, unfurls the story of Virmati. The author additionally depicts the idea of Virmati and her desire after death gives her demeanor. She says: "When I die, she said to me, I want my body donated. My eyes, my hearts, my kidneys, any organ that can be of use. That way someone will value me after I have gone”. (Kapur, 3)

Ida, the ever detached girl, goes to Amritsar to reconstruct her mother's memory. The writer capably oversees the over a wide span of time in the novel. Ida a divorced young lady attempts to remember the memory of her mother. She informs that her mother is a strong and forceful woman who fought against the malevolent traditions of the general public. Her mother is looking for her own identity in customary Indian culture. Virmati was raised in the conventional Indian family. She is occupied with family unit obligations. She lost her identity in family duty. The novelist through Virmati uncovered the truth of Indian woman in the family. She is just a manikin in the hand of a male. Virmati had consistently told by her mom that marriage is a definitive destiny of the woman. Since Virmati was the oldest little girl of Kasturi, she had to take care of every one of her siblings and sisters and she helped her mother in the upbringing of every one of them. During the pregnancies of her mother, Virmati was consistently occupied in orchestrating the house-hold undertakings and dealing with the thing concerning as workable for her. Kapur expounds on her obligations in these words:

"Ever since Virmati could remember she had been looking after children. It wasn "et only baby Parvati to whom she was indispensable, to her younger siblings 
she was second mother as well. She was impatient and intolerant of fuss. If they didn"t eat their meals, on her return home from school she would hunt out the offending brother or sister and shove the cold food down their throats. If they refused to wear the hand-me-down clothes she assigned them, she slapped them briskly. Sometimes she tried to be gentle, but it was weary work and she was almost always tired and harassed". (Kapur,6)

It appears that Virmati had to handle the duty in her initial age. In this way, Virmati is depicted as a typical Indian woman. She has invested the greater part of her energy in the households. In spite of the fact that she wishes to spend her life openly without assuming any liability, she is bound in the households. She represents the modern woman. She battles against the traditional Indian male predominant society. Living in Amritsar gives Virmati a chance to enter in the new domain of opportunity of which she was denied for a more drawn out period. Here, Manju Kapur appears to portray an account of a young lady whose excursion is very representative because of her change from "honesty to encounter". Manju Kapur likewise appends the topic of women's liberation with the character of Virmati. Virmati is by all accounts the victor of women's liberation in this novel. In Amritsar, her dresses, her standpoint, her appearance and her style - everything changes in a stroke. Manju Kapur assets

"Her dress too had changed from her Amritsar days. When they went visiting she wore her saris in Parsi style, as Shakuntala called it, with the palla draped over her right shoulder. The saris were of some thin material, 
foreign, with a woven silk border sewn onto them. The blouses were of the some thin material, with loose sleeves to the elbows- she wore her hair with a side parting, smoothed over her ears into a bun at back. Her shoes were black, shiny, patent leather with high heels. Her jewellery consisted of a strand of pearls, a single gold bangle on one arm, and a large man's watch on the other."(Kapur, 16)

Manju Kapur truly explains the realities of a conventional Indian family. It is where the woman is substandard. Shakuntala, a cousin of Virmati, who studied at Lahore, is now modern in life. However, the family of Virmati is additionally against the modernization of women. Indeed, they can't acknowledge the adjustment in the life of a woman. Be that as it may, Virmati is pulled in towards the way of life of Shakuntala. She believes that Shakuntala's life is free. She isn't bound in preservationist thinking. Furthermore, she is liberated from family households. Here, the author talks about two different ladies. Shakuntala is progressed and taut. She knows about her obligations. She is not bound in the enclosure of old custom and family obligation. Then again, Virmati is a common Indian young lady. She is bound in the family obligation. Her wants are constantly, evaporated in the everyday battle. Her dreams and expectations are converged in the old convention.Shakuntala avers on it:

“These people don't really understand Viru, how much satisfaction there can be in leading your own life, in being independent. Here we are fighting for the freedom of the nation, but women are still Supposed to marry, and nothing else.” (Kapur, 17) 
Manju Kapur intentionally utilizes the free world. In the novel, she utilizes the battle for freedom. She additionally portrays the battle of the country and Virmati. The author uncovered the circumstance of woman during the freedom struggle of India. The country has changed during the freedom struggle. Be that as it may, the predicament of a woman was unaltered. Virmati really believes that she should carry on with her life like Shakuntala. She wants to carry on with free lifewithout pressure and obligation. She wishes to break the shackles of family duty and live free lifelike her cousin. Yet, there is a contrast between dream and reality. Virmati's friendship with Shakuntala gives her chance to jump profound into the nectar of freedom which she understands outside the house. For her, training implies the acknowledgement of freedom and another standpoint and mentality. Virmati and Shakuntala always found in discussion on the issue of education and freedom. Virmati tells Shakuntala: "No, no really", said Virmati, catching her hand. May be here was the clue to her unhappiness. It was useless looking for answers inside the home. One had to look outside to education, freedom, and the bright lights of Lahore Colleges.” (Kapur,17)

In Shakuntala, Virmati detected the genuine signs of joy which must be acknowledged through opportunity. She watches the exercises of Shakuntala with watchfulness. She dreams to be with Shakuntala one day. She feels that she will be no more in Amritsar in light of the fact that there is no genuine freedom in Amritsar for her.Manju Kapur writes:

"Through the ensuing day"s Virmati followed Shakuntala around. She watches her ride horses, smoke, play cards and badminton, act without her mother"es advice, buy anything, she wanted without thinking it is a waste of money, casually drop in on all the people the family knew. 
Above all, she never seemed to question or doubt herself in anything." (Kapur,18.)

However, Virmatiee issue is something else. Albeit remotely she has been roused by Shakuntala, however, her issue is various. Virmati has likewise to modify her five sisters hanging tight for their marriage. Her family is very cognizant on the grounds that she is the oldest one. Her mother is likewise of a similar sentiment. She might want to play out the marriage of her little girl as quickly as time permits. Kasturi is likewise mindful of the transformational mentality of Virmati. She understands the unavoidable changes in her developing little girl. In any case, she is in issue whether to free her little girl or then again to check her development. She is by all accounts in wavering. She doesn't permit Virmati to enter in the domain of training with such freedom and yet, she wouldn't like to put the weights of conventions and shows on her girl. Be that as it may, Virmati wished to concentrate further, as opposed to marriage and bringing forth children. Her family dismisses her desire. Indeed, her mother has never bolstered her. Virmati's mother, Kasturi, too chokes between her sentiments and family obligations. The writer, through these female characters, uncovered the truth of Indian culture. The women's in the standard Indian family never remember their identity. She is a girl, sister, spouse and mother of somebody. They have no self-identity. Also, in the event that she attempted to set up her own identity, society never acknowledges it. Difficult Daughters is positively a thoughtful story of inconvenience in the life of an emotional young woman who is by all accounts battling in the male-overwhelmed society which gives a little space to the woman as a rule.

Virmati refused to get married to Inderjit. This strong advance by Virmati upsets everyone in her family. They feel that she has disfavored the family and destroyed her sister's odds of marriage. After the forswearing of the proposition to be engaged, her 
condition gets basic. The writer significantly conveys the issue of lady insufficiency. She characterizes the situation of debased because of steadfastness. She has no option to take her own choice. The male incomparability makes an obstacle in their lives. Virmati never chooses to pick her affection or further training. Be that as it may, frustrated with her affection, Virmati makes an endeavor of self-destruction. At last, they lock her in the godown and orchestrate Indu, her more youthful sister to wed Inderjit. Virmati is resolved to proceed with her studies at Lahore. Virmati chooses to go to Lahore for her further studies. All the relatives are against her choice yet they would do nothing before the desire of Virmati. As chosen by the family older folks, Kasturi needs to go with Virmati to Lahore for helping her to take affirmation in RBSL School and the chief guarantees Kasturi that there will be no issue. Virmati turns into the focal point of core interest in view of her progressive enthusiasm. She doesn't respect the deep-rooted customs of her Arya-Samaj family. In Lahore, she finds the organization of Shakuntala who consistently rouses her to be free and dynamic in her standpoint and way. Shakuntala informs Virmati regarding the individuals of Lahore that they are not intolerant.

She begins a significant life in Lahore with her flat mate Swarna Lata. Swarna Lata is a functioning member of the political and social developments of the day. Swarna Lata, a functioning extremist for women's freedom and liberation. She is an advanced woman with her own perspectives and conclusions. She thinks autonomously. She needs to accomplish something other than a wedding. Instead of sitting tight for any man she sits under the shade of companion like Swarna Lata, Virmati endeavors to examine the public strain required during the Indian freedom struggle. In any case, the professor's musings continue hovering around her psyche. Harish comes to meet her in Lahore. They meet and make a mind-blowing most. The educator shows his sexual 
tendency with Virmati. On the other hand, Virmati couldn't decrease the advances of the educator. Virmati is aware of the idea of her relationship with the educator however her opposition isn't long. After this demonstration of sexual inclusion, Virmati is by all accounts trapped in the feeling of blame. She understands the ethical slip by in her heart and a feeling of blame runs through her psyche. Manju Kapur flawlessly connected the character of Virmati in the exercises of freedom development which was on peak those days. Virmati went to numerous gatherings composed of different gatherings in which the subject identified with the woman strengthening was likewise examined. She went to those meetings and heard numerous discourses conveyed by Leela Mehta every now and then. Virmati couldn't generally make out the opportunity she was focusing on. She needs in her internal identity to resemble Swarna Lata, her flatmate. At the point when she goes for a gathering composed by women's for the freedom struggle, watching all the ladies effectively taking an interest in freedom struggle she thinks herself includes herself in others. She avers:

"Am I free, thought Virmati. I came here to be free but I am not like these women. They are using their minds, organizing, participating in conferences, politically active, while my time is spent in love. Wasting it.” (Kapur,142.)

Regardless of her regular solicitations, Harish is hesitant to wed her. He appears to be simply one more extremist saturated with male-centric conventions. He is a twotimer who, at his own accommodation, has shaped his assessments about social conventions and explicitly misuses Virmati. Virmati gets pregnant. At that point, she goes to Amritsar and deals with a gold bangle from her dad however just to sell it for her premature birth. After this discouraging occurrence, she chooses not to engage the educator any more. Virmati reprimands the educator for this disaster in her life. She avers to the professor: 
"I break my engagement because of you, blacken my family's name, am locked up inside my house, get sent to Lahore because no one knows what to do with me. Here I am in the position of being your secret wife full of shame, wondering what people will say if they find out, not being able to live in peace, study in peace... and why? Because I am an Idiot." (Kapur,149)

Despite the fact that Virmati prevails to wed the professor yet she doesn't make sure about any space for herself in the family. Ganga and Harish's mother urges Virmati to have a stifling existence in the tight dividers of the house. It is noteworthy to take note of that Virmati who gets high training notwithstanding social chances and obscurities tries to play the conventional job of a house spouse with the goal that she may care for the unremarkable needs of her better half however she isn't permitted to. She isn't recognized for her learnedness then again Harish deserves admiration for his educational thoughts and belief systems. On occasion, it appears that Harish and Virmati as a team doesn't have shared friendship. In a spouse husband tattle when Virmati proposes a name for their inevitable infant that has been impartially dismissed by the professor. The professor was not accommodating and quiet in his choice and he additionally exacts a long lecture on Virmati so as to silence her.

In this way, one can infer that Virmati being raised in a dynamic family is instructed and presented to western thoughts. She resists the family and follows her heart. She battles a great deal to get his own identity. In her mission of Identity, she loses it at each stage and battles to make space for herself all alone. Her insubordinate mentality reclaims stages at whatever point it must be solid to invalidate Harish's sexual abuse. Manju Kapur shows consistent exertion to combine the situation of 
woman in Indian culture. The excellence of her novel surely lies in her exceptional introduction where she appears to introduce clashing circumstances in which women are looking for their own independent identity and area. 


\section{References}

Alexander, Vera. "The Representation of Education in Indian novels in English." Mediating Indian writing in English: German Responses. Eds. Bernd-Peter Lange, Mala Pandurang. London: Transaction, 2006. Print.

Chandra, Vikram. "Quoted on the back page of Difficult Daughters." Londan: faber and faber, 1998.

Chakravarty, Joya. "A study of Difficult Daughters and A Married Woman." Indian women novelists in English. Ed. Jaydipsinh Dodiya. New Delhi: Sarup, 2006. print.

Kapur, Manju. “Difficult Daughters.” Londan: Faber and Faber, 1998. p.01. Print.

Kapur, Sanjay. "Transcending Gender Parochialism in modern Indian feminist fiction." Ed. Mishra Binod and Kumar sanjay Indian writing in English. New Delhi: Atlantic Publishers and distributors, 2006.

Nayak, Bhagabat. "Feminist Assertions in Manju Kapur: A Socio-Ethical perspective." The Indian journal of English studies, Vol. Xl1. 2003. Print.

Sinha, Sunita. "Discovery of Daring and Desire in Manju Kapur's fiction.”Postcolonial women writers: New perspectives, New Delhi: Atlantic, 2008. Print. 